\title{
Lumen
}

Selected Proceedings from the Canadian Society for Eighteenth-Century Studies

\section{'Are We "Voltaire's Bastards?"' John Ralston Saul and Post-Modern Representations of the Enlightenment}

\section{Nicholas Hudson}

Volume 20, 2001

URI : https://id.erudit.org/iderudit/1012306ar

DOI : https://doi.org/10.7202/1012306ar

Aller au sommaire du numéro

Éditeur(s)

Canadian Society for Eighteenth-Century Studies / Société canadienne d'étude du dix-huitième siècle

ISSN

1209-3696 (imprimé)

1927-8284 (numérique)

Découvrir la revue

Citer cet article

Hudson, N. (2001). 'Are We "Voltaire's Bastards?"' John Ralston Saul and Post-Modern Representations of the Enlightenment. Lumen, 20, 111-121. https://doi.org/10.7202/1012306ar

Copyright (c) Canadian Society for Eighteenth-Century Studies / Sociéte canadienne d'étude du dix-huitième siècle, 2001
Ce document est protégé par la loi sur le droit d'auteur. L'utilisation des services d'Érudit (y compris la reproduction) est assujettie à sa politique d'utilisation que vous pouvez consulter en ligne.

https://apropos.erudit.org/fr/usagers/politique-dutilisation/ 


\section{8. 'Are We "Voltaire's Bastards?"” John Ralston Saul and Post-Modern Representations of the Enlightenment}

While no enemy to amorous pleasures, Voltaire left no actual children that we know about. According to John Ralston Saul, however, our late twentieth century is still ruled by the ideological progeny of the rationalist ideals that Voltaire spent his life conceiving. In taking a generally negative view of this legacy, Saul joins a now large group of post-modern theorists who have traced the alleged errors and oppressions of our time to the arrogant rationalism of the eighteenth century. Beginning with Horkheimer and Adorno's Dialectic of Enlightenment more than fifty years ago, and continued in recent books by John Gray, Karlis Racevskis, Michael Luntley and others, the eighteenth century has been blamed for inaugurating the West's careless faith in technology and science, its belief in the centered self and a transparent language of denotation, its oppressive mission to remake the world in its own image, and other forms of philosophical and political dogma that post-modernism sets out to deconstruct. ${ }^{1}$

As a writer of non-academic history and sociology, Saul may seem out of place among the professional historians and philosophers who have launched this anti-Enlightenment critique. Yet Voltaire's Bastards reveals a great deal about a perception of the eighteenth century and its legacy that, given the great popularity of Saul's book, seems widely disseminated among highly educated people. Outside of our seminar rooms, those who have any conception of the eighteenth century at all tend to assume that we study men and women whose geometric dreams of a rational world still dominate our culture. That this is an exaggerated or inaccurate picture of the Enlightenment (as argued by certain historians such as Peter Gay), is not an argument that has made much headway against the popular outlook. Nor is it one that I can dismantle in this short paper. Nonetheless, I would like to approach Voltaire's Bastards as representative of a certain kind of post-modern historiography, and to argue that it routinely ignores important and characteristic features of 
French and British thought in the eighteenth century. Indeed, as I will conclude by suggesting, recent representations of this age reveal a suppressed and neurotic consciousness among post-modernists concerning their own status as, to adopt the metaphor in Saul's title, the illegitimate off-spring of the Enlightenment. Voltaire's most confused and vociferous bastards, we might say, are post-modernists themselves.

To link Saul with post-modernism might seem inaccurate. His passing remarks on most kinds of recent post-modernist scholarship reveal reactions ranging from disinterest to outright hostility: he excoriates deconstruction, for example, for epitomizing precisely the kind of selfobscuring elitism that he condemns in most late twentieth-century ideologies and institutions. ${ }^{2}$ Against the flow of post-modernist thought, Saul bravely (or naively) ties his flag to the masthead of 'Humanism,' arguing that our institutions have lost touch with human feelings and the common good. ${ }^{3}$ In an important sense, however, Saul's analysis does draw on the post-modernist critique of the Enlightenment. The danger of the Enlightenment tradition, Saul maintains, is that it has lost touch with its own status as an 'ideology' or even, in a figurative sense, a 'religion.' As he writes in the epigraph of his book, 'Reason is a narrow system swollen into an ideology ... Like most religions, reason presents itself as the solution to the problems it has created. ${ }^{4}$ In the pages that follow, he argues that rationalism presents itself as 'disinterested inquiry' when in fact it is a self-justifying and self-perpetuating system for an elite of politicians and executives, bureaucrats and academics, who have become a new double-breasted and blow-dried incarnation of the Ancien Régime. Saul assiduously avoids the term 'discourse.' Yet in denying the objective status of rational inquiry, which he regards as a disguised form of ideology or semiotics, he reveals the influence of post-modern ideas on his thinking. The ghost of Michel Foucault, though never mentioned, stalks at the fringes of Voltaire's Bastards.

The link with Foucault lies partly in the explosion of the supposed objectivity of rationalist discourse, but it is also revealed in Saul's preoccupation with rationalism as a system of power. Reason, in Saul's view, has its appropriate role as a guide for the administrative systems needed to serve the common good. Instead, the mere serving of rational administration has become an end in itself. Those who succeed best in Western cultures are increasingly those who conform with the bureaucratic or corporate structures around them, and who have no ideals or values besides the efficient exercise of power. The result of this domination by colorless apparatchiks has been, ironically, a culture of profound inefficiency where, for example, the US military spends trillions of dollars on an army it never uses and bloated multi-national corporations perform their slow, whale-like and useless courtship of merging. The cabinet 
ministers and bank presidents whose bland faces fill our newspapers specialize in an obscure doublespeak garnished with statistics and abstruse reasonings meant to prove that nothing can be changed, and that all events are determined by global forces beyond our control. These men and, increasingly, women convey a pessimism that Saul considers the most disempowering legacy of the Enlightenment. The new rational elite, he observes, pose as philosophes, dismissing all objections as the ludicrous theology of lefties and Utopians. In fact, their real ancestors are the courtiers who, in the Ancien Régime, occupied more appropriate administrative roles such as stamping customs forms and carrying the king's hat.

These paper-pushing elites are the 'bastards' named in Saul's title, so-called for their utter selfishness but also for their status as the illegitimate progeny of the Enlightenment. Saul's book opens with this analogy between illegitimacy and rationalism's unintended engendering of the modern bureaucratic elite:

In moments of great passion, the mind tends to be flooded with a warm vision of the person in our arms. We are unlikely, at this point, to be analyzing their flaws, real or hypothetical ... As for the possible product of our intercourse, only the most peculiar lover would be fretting, while in the act, over whether such a child might or might not be an appropriate and worthy creation. ${ }^{5}$

Just so, Saul goes on, did the philosophes throw themselves 'into the arms of reason' without realizing that they were spawning Brian Mulroney and Matthew Barrett, and not the generations of public-spirited rationalists they had envisioned. Saul's image describes a historical process similar to what Horkheimer and Adorno called the 'dialectic of Enlightenment,' this era's unintended creation, in a new form, of the oppression that it sought to dismantle. For Horkheimer and Adorno, the paradox of the Enlightenment was that its insistence on facts demystified religion and debunked superstition, yet also blinded the inheritors of the rationalistic tradition to the limitations of their own factual and calculating mentality. 'Intolerant of mystery, ${ }^{\prime 6}$ the Enlightenment lost all trace of the critical and self-conscious spirit that once animated its attacks on authority: 'Ruthlessly, in spite of itself, the Enlightenment has extinguished any trace of its own self-consciousness. The only kind of thinking that is sufficiently hard to shatter myths is ultimately self-destructive. ${ }^{.7}$ Saul's thesis is less deterministic than Horkheimer and Adorno's: his point is not that rationalism inevitably causes its own destruction but rather that confidence in reason became too unreflective and dangerously unmoored from the moderating influence of ethical structures. Nevertheless, Saul's analysis of the ills of our time is, in many respects, very similar 
to that of his more academically illustrious predecessors in the Frankfurt School. Like them, Saul diagnoses the bad influence of the Enlightenment in the allegedly debased language of the present age, from the empty slogans of advertising to the cabalistic codes of academic specialties. He finds the same mechanical and hollow repetition in the latest heroes stamped out by the media and in our strangely superstitious idolatry of images such as the golden arches and Mickey Mouse. The movement that once assailed elitism and superstition, in short, finally transmogrified into a mere facade of its former intentions, even the unintended and paradoxical inversion of its ideals of clarity, factuality and individualism.

The question raised by these attacks on the Enlightenment tradition is this: to what extent should the Enlightenment be held responsible for initiating the train of events in Western culture that finally led to the supposed hegemony of rationalist ideologies and institutions in our own time? It is worth noting, first, the profoundly Gallocentric nature of discussion concerning the Enlightenment, a term that can be applied only with considerable qualification, if at all, to eighteenth-century Britain. This is significant because Saul, like most previous authors, finds the legacy of the Enlightenment most fully revealed in the culture of the United States, whose roots lie not in France, but in the radical dissenting culture of seventeenth- and eighteenth-century England. This culture was not predominantly 'rationalist': it was intensely Christian, evangelical and inspirational. It regarded the world as a drama of signs and miracles, not as an indifferent mechanism of natural laws. It was not particularly philosophical or even literate: as the social historian M.J. Daunton points out, eighteenth-century immigrants to the American colonies came largely from the class of journeymen artisans, men and women far more likely to stock their bookshelf (if they had one) with sermons and almanacs than with the translated works of Voltaire or Montesquieu. ${ }^{8}$ While fiercely independent, industrious and acquisitive, this group tended to consult the dictates of sentiment rather than reason. As Andrew Burstein has recently maintained in Sentimental Democracy: The Evolution of America's Romantic Self-Image, early American political language drips with the heart-throbbings and tears of a people who tended to equate strong feelings with truth. ${ }^{9}$ And it is easy to see that this legacy is alive and well in the sentimentality of American political and cultural life even to this day.

It is, in short, highly problematic to trace the behavior of this century's dominant power to the theoretical outlooks of eighteenth-century philosophers. Nor is it clear that post-modern critics of the Enlightenment have conveyed an accurate impression even of this philosophical tradition. Consider David Hume, who was an avowed opponent to rational- 
ism and for this reason is often excluded from what historians call the 'Enlightenment.' Yet this renowned skeptic was by no means departing radically from the empiricist tradition that arose from the work of John Locke and dominated philosophy during the first half of the eighteenth century. Hume was agreeing with Locke, for example, in rejecting the existence of any innate ideas or a priori rational knowledge. Ideas, according to both, derived entirely from the senses, and knowledge, in Locke's definition, was only 'the Perception of the Agreement, or Disagreement, of any of our Ideas. ${ }^{10}$ Locke differed from Hume principally in introducing an ill-defined faculty named 'intuition' as the means by which we discern this agreement or disagreement of ideas: in Locke's view, this 'intuition' appears to assure that certain basic agreements of perceptions, such as cause and effect, correspond with real events in the material world. ${ }^{11}$ Here was an inference denied by Hume. Yet Locke's empiricism implied severe restrictions on human knowledge that the famously skeptical Hume was extending or sharpening, not overturning. Given that we can have no knowledge beyond the senses, for example, Locke denied that we have any idea at all of the nature of matter, the soul or personal identity, which he reduced merely to the consciousness of having certain experiences and memories. Locke's universe is a hollowed-out universe where the 'real essence' of the self and all things is forever beyond our understanding. Not only does this vision contain the seeds of everything Hume said about knowledge, but on certain questions Locke was arguably even more skeptical than the later Scottish philosopher, as on questions of morality. Locke determined that moral propositions were what he called 'mixed modes' - that is, ideas brought together only in the human mind, and then given a name. Hence, the ideas of father and killing are brought together to form the mixed mode we call 'parricide.' This analysis offended many of Locke's orthodox contemporaries, and even free-thinkers, because Locke denied that mixed modes corresponded with any external or objective standard. In his words, 'the Names of mixed Modes are uncertain, because there be no real Standards existing in Nature, to which those Ideas are referred. ${ }^{12}$ For this reason, Locke argued, there is considerable diversity in what various nations call 'virtue' and 'vice,' terms that stand only for actions that we commonly praise or blame. Against such skepticism, even Locke's admirers in the eighteenth century generally wanted to retain some reliable standard of moral truth, though most were unwilling to return either to revealed religion or the standard of 'natural law' set out by ethical and legal theorists of the seventeenth century such as Grotius, Pufendorf and Samuel Clarke. For an increasing number of writers, the alternative was to situate moral discernment not in reason but, again, in the sentiments, our heartfelt intuition of good or evil. This 
was the kind of ethical doctrine developed by Shaftesbury, Hutcheson, Fielding and later the framers of the US constitution, such as Jefferson. It was also the view developed by the anti-rationalist Hume, and it underlines again a general movement in eighteenth-century thought away, and not towards, the pre-eminence of reason in philosophical discussions of knowledge and truth.

I have recalled these fairly elementary features of eighteenth-century philosophy in order to raise questions concerning the accuracy of postmodern accounts of this age as characterized by a dogmatic and selfdeluded confidence in reason. Indeed, in the eyes of most commentators of the eighteenth century, this was not an age of expanding confidence in reason but of growing skepticism, care and conservatism. To cite Peter Gay, one of the few modern historians to acknowledge this antirationalist trend, 'the philosophes' glorification of criticism and their qualified repudiation of metaphysics make it obvious that the Enlightenment was not an Age of Reason but a Revolt against Rationalism. ${ }^{\prime 13}$ Here we might turn to the eponymous hero or villain of Saul's work, the very dean of the philosophes, Voltaire. In his Lettres philosophiques, Voltaire draws a sharp distinction between the rationalism of the age of Descartes, characterized by an excessive confidence in human powers, and his own time, which he regards as the much different and more skeptical age of Newton and Locke. Here, for example, he imagines an admirer of Locke responding to Descartes's philosophical case for the existence of the soul:

Confessez du moins que vous êtes aussi ignorans que moi, votre imagination ni la mienne ne peuvent concevoir comment un corps a des idées, \& comprenezvous mieux comment une substance, telle qu'elle soit, a des idées? Vous ne concevez ni la matiere ni l'esprit, comment osez-vous assurer quelque chose? ${ }^{14}$

Voltaire did assert that Descartes had exercised a beneficial influence on philosophy by stipulating, in the first precept of his method, that nothing should be concluded without certain evidence. Unfortunately, Descartes and his followers had betrayed their own lesson, speculating widely and carelessly on matters beyond the reach of reason. They produced the grand cosmological systems typical not only of Cartesians like Malebranche and Rouhault, but also of other seventeenth-century thinkers like Leibniz, Spinoza and Cumberland. This system-making had come to an end in the eighteenth century. As Voltaire went on in his Lettres philosophiques, 'aujourd'hui tous les recueils des Académies de l'Europe ne font pas même un commencement de sistème: et aprofondissant cet abîme, il s'est trouvé infini. ${ }^{15}$ 
This skepticism concerning the powers of reason hardened as Voltaire grew older. At the time he wrote his Lettres philosophiques, for example, he still admired the theodicy of Pope and Bolingbroke, who followed Leibniz in concluding that all apparent evil was universal good, and 'Whatever is, is right.' Almost a quarter-century later, in Candide, Voltaire had deflated this grandiose optimism into the pathetic and battered form of the philosopher Pangloss. By this point in his career, Voltaire accepted little beyond the evidence of the senses, and this thoroughgoing empiricism imposed even narrower bounds on human knowledge. In his Dictionnaire philosophique, he repeatedly satirized the arrogance of philosophy. 'Mettons à la fin de presque tous les chapitres de métaphysique les deux lettres des juges romains quand ils n'entendaient pas une cause, N.L. non liquet, Cela n'est pas clair. ${ }^{16}$ A similarly conservative declaration follows in his article 'Bornes de l'esprit humain': 'Je pourrais te faire un folio de questions, auxquelles tu ne devrais répondre que par quatre mots, Je n'en sais rien. ${ }^{17}$

It is difficult to see how this skepticism, which is typical not only of Voltaire but of other major authors on both sides of the English channel, is consistent with Horkheimer and Adorno's condemnation of the Enlightenment as 'intolerant of mystery. ${ }^{18}$ And if we look into other recent books on post-modernism, we discover an even more cavalier indifference to the skepticism and doubt common in eighteenth-century thought. Here are the words, for example, of Michael Luntley in his 1992 book Reason, Truth and Self: The Postmodern Reconditioned:

For the Enlightenment thinker, truth was available. Human reason was the tool by which this knowledge had been achieved and, by further application of human reason, one day the whole truth would be available to the human mind. ${ }^{19}$

Reading this and similar assessments of the Enlightenment by Isaiah Berlin, John Gray, Karlis Racevskis and others, we must conclude that they have little to do, in fact, with what was actually said or thought in the eighteenth century. Rather they constitute a historical construction meant to justify post-modernism's conception of itself as a radical demystification of modern thought. The notion of the Enlightenment as 'the Age of Reason,' lacking in understanding of its own limitations, routinely ignores massive evidence to the contrary, and fails to account for the important shift in Western thought with the rise of empiricism after Locke.

Ironically, then, John Ralston Saul is at something of an advantage in being less confined than most academic writers by the governing prejudice of mid and late twentieth-century historiography. While he does adopt the image of the Enlightenment as an 'Age of Reason,' he also 
allows himself to be influenced by what he has read in the works of the philosophes. These impressions lead him to a fresher and more balanced view of eighteenth-century thought that recognizes the spirit of criticism and doubt that inspired the writings of Voltaire, Diderot and Rousseau. Indeed, we might finally give some attention to Saul's own links with these figures as a satirist of modern systems of authority. In his skepticism, wit and irreverence, the author of Voltaire's Bastards may well be seen as himself the progeny of Enlightenment thought.

This proposition is more complicated than might initially appear, for Saul's parents in the eighteenth century are more than one. Perhaps his most paradoxical affinity is with a writer who, like Saul, was bitterly opposed to the self-serving abstractions of rational politicians, yet who also belongs to a conservative political heritage that Saul, as a famous lefty, is supposed to despise. This is Edmund Burke, whose Reflections on the Late Revolution in France (1792) Saul quotes with a revealing mixture of approval and discomfort. As he observes of Burke's opposition to the revolution, 'Some of his arguments were brilliant; others were patently wrong. France was not a country he knew a great deal about and so, out of ignorance, he praised the ancien régime. ${ }^{20}$ We may well baulk at the notion that Burke supported the Ancien Régime merely because he did not understand France: Burke understood France well enough to feel incensed that traditional ideals and institutions were being desecrated and dismantled by innovating theorists. The ambivalence of Saul's reaction derives mostly from himself, not from Burke. Saul obviously feels sympathy for Burke's dismay that the bourgeois professionals who led the French Revolution (as they today lead virtually all the institutions in the Western world) had no respect for the ideals that Burke took as 'natural,' and not merely as the vestiges of an outgoing ideology. Even in Burke's famously sentimental portrait of MarieAntoinette, the glowing star of royalty disgraced and violated by the greasy canaille, there is a link with Saul's advocacy of 'humanism.' For Saul, 'humanism' stands for the ethical values that he considers beyond questioning, the principles of public-spiritedness and democracy abandoned by the visionless bureaucrats and number-crunchers of our rational age. While offended by the violation of these values, however, Saul does not want to align himself with a conservative thinker who felt the urge to unsheathe his sword in defense of a queen that Saul denigrates as an Ancien Régime version of Madonna. Like Burke, Saul wants to safeguard attitudes that he considers 'natural,' but he does not want to feel that this form of conservatism is merely unreflective or prejudiced.

For Saul wants, in part, to be like the philosophes whom Burke opposed. An inherent though unprofessed irony of Voltaire's Bastards is that its author in fact resembles no historical figure more than Voltaire. The 
resemblance lies most obviously in Saul's witty defiance of the reigning conventions and pieties of our age. He prophesies that we are witnessing the dying corruptions of rationalist autocracy, and he stands with his guillotine eagerly awaiting the first trundle of bank-presidents and ministers of finance. Yet the resemblance with Voltaire goes even deeper, and is marked by the ironies also inherent in the career of his predecessor in the eighteenth century. For all his irreverence, Voltaire was a man enamored with the life of the court and the privileged world of the aristocracy. He thirsted for recognition at Versailles and when it was not served with sufficient flourish, he escaped to Berlin, where he showed himself entirely willing to set aside his anti-militarism in obeisance to the bellicose, if belletristic, Frederick the Great. Voltaire was not without democratic and populist impulses, which showed themselves in his defense of the natifs in Geneva and his courageous campaigns in favor of victims of religious persecution such as Calas and La Barre. But one cannot not help noticing that both Voltaire and the husband of our Governor-General tend to view the world's sufferings through the baywindows of large houses. Part of the fun of Voltaire's Bastards is that Saul seems to know many of the people he attacks. His understanding of culture, like Voltaire's, concentrates on the role of the 'elite,' whom he both blames for social dysfunction, and loads with the responsibility of leading the masses out of darkness. If part of Saul is repelled by the theoretical devotion to the Ancien Régime displayed by Burke (in fact an Irish outcast, a man who never tasted power), another side of him shares Voltaire's role as the mischievous but ultimately well-tailored intimate of those in places of influence.

In this role as the strange, illegitimate off-spring of a union between Voltaire and Edmund Burke, Saul perhaps reveals something important in a general sense about recent representations of the eighteenth century. The metaphor of illegitimacy, so central to this book's conception of our post-modern age, may well be extended to the other authors that I have mentioned. Like Saul, these authors experience intense, even neurotic conflict with regard to their own intellectual paternity in the Enlightenment. One thinks, for example, of Paul De Man's brilliant observation that Jacques Derrida's Of Grammatology both denies yet duplicates the deconstructive paradoxes of Derrida's principle subject, Jean-Jacques Rousseau. ${ }^{21}$ The Enlightenment is an arrogant and even abusive father that we frequently wish to disown, yet even those most hostile to this influence continue to show a family resemblance. This resemblance is most clearly belied in the penchant for irreverent critique, the fierce independence and, on the negative side, the maddening social hypocrisy of the privileged burger who denounces the world from his chair at a well-stocked table. In denouncing the Enlightenment as an overbearing 
and narrow-minded bastard, we are revealing our own debts to the critical and irreverent spirit of that age. Whether we like it or not, it seems, we are all Voltaire's bastards, and our denial of this heritage only involves us more deeply in self-defeating paradox.

\section{NICHOLAS HUDSON}

\section{Notes}

1 See Theodore W. Adorno and Max Horkheimer, Dialectic of Enlightenment, trans. John Cumming (London: Allen Lane, 1972); Karlis Racevskis, Postmodernism and the Search for Enlightenment (Charlottesville and London: University Press of Virginia, 1993); John Gray, Enlightement's Wake: Politics and Culture at the Close of the Modern Age (London and New York: Routledge, 1995); Michael Luntley, Reason, Truth and Self: The Postmodern Reconditioned (London and New York: Routledge, 1995); Renhart Koselleck, Critique and Crisis: Enlightenment and the Pathogenesis of Modern Society (Oxford, New York, and Hamburg: Berg, 1988); Isaiah Berlin, The Roots of Romanticism, ed. Henry Hardy (Princeton: Princeton University Press, 1999).

2 See John Ralston Saul, Voltaire's Bastards: The Dictatorship of Reason in the West (Harmondsworth: Penguin, 1992), pp. 111 and 563.

3 See Saul, pp. 581-4.

4 Saul, p. 3.

5 Saul, p. 5.

6 Adorno and Horkheimer, p. 5.

7 Adorno and Horkheimer, p. 4.

8 See M.J. Daunton, Progress and Poverty: An Economic and Social History of Britain 1700 - 1850 (Oxford: Oxford University Press, 1995), pp. 412-14.

9 See Andrew Burstein, Sentimental Democracy: The Evolution of America's Romantic Self- Image (New York: Hill and Wang, 1999).

10 John Locke, An Essay Concerning Human Understanding, ed. P.H. Nidditch (Oxford: Clarendon Press, 1975), bk. 4, chap. 3, sec. 1, p. 538.

11 'In every step Reason makes in demonstrative Knowledge, there is an intuitive Knowledge of that Agreement or Disagreement, it seeks, with the next intermediate Idea, which it uses as a Proof' (Locke, bk. 4, chap. 2, sec. 7, p. 533).

12 Locke, bk. 3, chap. 9, sec. 11, p. 481.

13 Peter Gay, The Enlightenment: An Interpretation, 2 vols. (New York: Alfred A. Knopf, 1966), 1:141.

14 Voltaire, Lettres philosophiques, ed. Gustave Lanson, rev. André Rousseau, 2 vols. (Paris: Librairie Marcel Didier, 1964), $13^{\mathrm{e}}$ lettre, 1:172-3.

15 Voltaire, Lettres philosophiques, $14^{\mathrm{e}}$ lettre, 2:7-8

16 Voltaire, Dictionnaire philosophique, in The Complete Works of Voltaire (Oxford: Voltaire Foundation, 1970 - ), 'Tout est bien,' 35:428. 
17 Voltaire, Dictionnaire philosophique, 35:429.

18 Adorno and Horkheimer, p. 5.

19 Luntley, p. 11.

20 Saul, p. 65.

21 See Paul de Man, 'The Rhetoric of Blindness: Jacques Derrida's Reading of Rousseau,' in Blindness and Insight: Essays in the Rhetoric of Contemporary Criticism $\left(2^{\text {nd }}\right.$ ed. Minneapolis: University of Minnesota Press, 1983), pp. 102-41. On this issue, see also Christie V. McDonald, 'Jacques Derrida's Reading of Rousseau,' The Eighteenth Century: Theory and Interpretation 20 (1979): 82-95. 